\title{
Tingkat Kesesuaian Ruang Publik dengan Konsep Livable City di Kota SURAKarta
}

\author{
Ifni Farida, Galing Yudana, Erma Fitria Rini \\ Program Studi Perencanaan Wilayah dan Kota \\ Fakultas Teknik \\ Universitas Sebelas Maret, Surakarta \\ email: ifnifarida@ymail.com
}

\begin{abstract}
Development of the urban population in Indonesia that growing rapidly these days, of course will cause impacts for the city itself, including in terms of environmental degradation. Therefore, society needs of a comfortable and livable city is getting higher, which is known as the concept of livable city. One of the key principles of the concept of livable city is the availability of public space as a place to socialize and interact. Surakarta, within 5 (five) years, being actively promote provision of public green space, as one of the public space, as evidenced by the increase of public green space area 23,16\% in 2016. In a study titled Indonesia Most Livable City Index, Surakarta has a livable city index reached $69,38 \%$ above the national average. The problem in this research is how the level of conformity of the public space in Surakarta with the concept of livable city? This study aims to determine the level of conformity of the public space in Surakarta with the concept of livable city, which covers several aspects, including: availability, coverage, accessibility, comfort, amenity, and supporting activity. The method in this study using deductive research approach and scoring analysis technique. Based on the analysis, it can be seen that the level of conformity of the public space in Surakarta with the concept of livable city included into the category of medium-level conformity. Nonetheless, it needs improvement in some aspects of public space in Surakarta whose value is still low, in order to realize the public space in Surakarta according to the concept of livable city.
\end{abstract}

Keywords: level of conformity, public space, livable city, scoring analysis

\section{PENDAHULUAN}

Masyarakat dewasa ini, menganggap perkotaan sebagai lokasi yang paling efektif dan efisien untuk berbagai kegiatan produktif. Anggapan ini kemudian menjadikan urbanisasi sebagai suatu fenomena yang tidak dapat dielakkan lagi dalam pembangunan kota-kota di Indonesia. Fenomena urbanisasi ini mempengaruhi perilaku manusia yang dari hari ke hari berkembang menjadi kegiatan yang lebih kompleks. Hal tersebut tentunya melahirkan dampak bagi perkotaan itu sendiri, salah satunya masalah lingkungan.

Akibat berbagai masalah lingkungan yang mendera kota-kota di Indonesia dewasa ini, masyarakat kota mulai mendambakan sebuah kota yang nyaman dan layak untuk dihuni. Konsep kota yang demikian dikenal dengan sebutan livable city. Konsep livable city merupakan gambaran sebuah lingkungan dan suasana kota yang nyaman sebagai tempat tinggal dan sebagai tempat untuk berkegiatan yang dilihat dari berbagai aspek, baik aspek fisik maupun aspek non-fisik (Ikatan Ahli Perencanaan Indonesia, 2009). Salah satu prinsip penting dalam konsep livable city adalah ketersediaan ruang publik sebagai tempat bersosialisasi dan berinteraksi.

Kota Surakarta merupakan salah satu kota di Indonesia yang menjadi kandidat sebagai peraih Indonesia Most Livable City Index. Penelitian ini dilakukan oleh Ikatan Ahli Perencanaan (IAP) Indonesia dengan cara survei di 17 (tujuh belas) kota di Indonesia yang memiliki pengaruh skala regional maupun nasional. Kota Surakarta ditetapkan menjadi salah satu kandidat kota paling nyaman dan layak huni karena kota tersebut telah menunjukkan kemajuan dalam hal perbaikan infrastruktur, utilitas, ruang publik, aksesibilitas, transportasi, dan kriteria lainnya. Hasil dari penelitian tersebut, Kota Surakarta memiliki livable city index mencapai 69,38\%, di atas rata-rata nasional yang hanya $63,62 \%$. Indeks tersebut didapatkan terutama dari aspek tata kota dan pengelolaan lingkungan yang dianggap terkelola dengan baik sehingga memperoleh indeks lebih besar dibandingkan kota-kota lain di Indonesia.

Kota Surakarta telah melaksanakan beberapa program dengan tujuan memperbaiki dan menyehatkan lingkungan Kota Surakarta, 
terutama dalam hal penyediaan ruang publik. Pada tahun 2011, bekerja sama dengan Direktorat Jenderal Penataan Ruang, Pemerintah Kota Surakarta telah berkomitmen dalam Program Pengembangan Kota Hijau (P2KH) ditandai dengan penandatangan piagam "Komitmen Kota Hijau".

Kota Surakarta telah membuktikan keseriusannya dalam menggalakkan ruang terbuka hijau publik sebagai salah satu bentuk ruang publik agar mencapai target pemerintah, dari luasan ruang terbuka hijau publik pada tahun 2011 yang hanya sebesar 11,9\% (Badan Penelitian dan Pengembangan Provinsi Jawa Tengah) kemudian meningkat pada tahun 2013 menjadi 12,02\% (Badan Lingkungan Hidup Kota Surakarta). Sedangkan pada tahun 2016, luasan ruang terbuka hijau publik Kota Surakarta sudah mencapai 23,16\% (Badan Lingkungan Hidup Kota Surakarta). Hal ini dapat diwujudkan karena keberhasilan program terkait ruang terbuka hijau publik oleh Pemerintah Kota Surakarta, antara lain: pembangunan Taman Urban Forest III di Kelurahan Pucangsawit, pembangunan Taman Sekartaji VI, serta perluasan hutan kota.

Dari permasalahan yang telah dijabarkan di atas, penelitian mengenai tingkat kesesuaian ruang publik dengan konsep livable city ini penting untuk dilakukan karena dapat mengetahui sejauh mana kesesuaian penerapan konsep livable city di Kota Surakarta yang ditinjau dari kondisi ruang publik, agar dapat disusun langkah-langkah terkait ruang publik guna mewujudkan Kota Surakarta yang livable di masa mendatang.

\section{TINJAUAN PUSTAKA}

\subsection{Konsep Livable City}

Hahlweg (1997) mendefinisikan livable city sebagai kota yang dapat menampung seluruh kegiatan masyarakat kota dan aman bagi seluruh masyarakat.

Menurut Salzano (1997), livable city adalah kota yang menghormati jejak sejarah masa lalu dan mengelola lingkungan untuk masa mendatang.

Definisi livable city menurut Evans (2002) merupakan kota yang mampu menyediakan lapangan pekerjaan dan melestarikan kualitas lingkungan.

Menurut Timmer (2006), definisi livable city mengacu pada sistem perkotaan yang memberikan kontribusi fisik, sosial, mental, dan pribadi terhadap penghuninya.
Sedangkan Ikatan Ahli Perencanaan Indonesia (2009) mendefinisikan livable city sebagai kota yang nyaman sebagai tempat tinggal dan berkegiatan dilihat dari aspek fisik dan non-fisik.

\subsection{Ruang Publik}

Menurut Ching (1992), ruang publik adalah ruang yang terbentuk atau didesain sedemikian rupa sehingga ruang tersebut dapat menampung sejumlah besar orang dalam melakukan kegiatan-kegiatan yang bersifat publik.

Carr (1992) melihat ruang publik sebagai ruang tempat masyarakat melakukan kegiatan fungsional maupun ritual dalam suatu ikatan komunitas.

Hakim (1987) menjelaskan bahwa ruang publik adalah wadah yang dapat menampung kegiatan masyarakat, baik individu maupun kelompok.

Dalam gagasan Scurton (1984), ruang yang dikatakan sebagai ruang publik adalah lokasi terdesain yang dapat diakses oleh setiap pengguna sebagai tempat bertemu untuk kegiatan sehari-hari.

\subsection{Ruang Publik dalam Konsep Livable City}

Public Policy Institute berpendapat bahwa lingkungan yang layak huni terdiri dari akses dan kenyamanan. Lingkungan yang ada berupa lingkungan kompak yang mempermudah masyarakat untuk mendapatkan apa yang mereka butuhkan, mulai dari tempat bekerja, pusat perbelanjaan, sampai dengan perpustakaan. Selain itu, juga taman dan tempat makan terdekat dilengkapi lingkungan walkable dengan akses yang baik. Untuk jarak yang lebih jauh tersedia transit atau kendaraan umum untuk membantu masyarakat mencapai tempat bekerja, fasilitas kesehatan, serta jasa yang lebih lengkap.

Kedekatan ruang publik menurut Public Policy Institute ini ditentukan dengan jumlah ruang publik dalam setengah mil yang diukur pada skala lingkungan, dan apabila jumlahnya lebih tinggi maka lebih baik. Ruang publik dalam konsep livable city menurut Public Policy Institute, memberikan kesempatan bagi masyarakat untuk berolahraga, bersosialisasi, serta menikmati alam bebas. Ruang publik menurut Public Policy Institute harus mampu ditempuh dengan berjalan kaki. Selain itu, ruang publik semestinya dilengkapi pula 
dengan fasilitas olahraga, taman bermain, dan lain sebagainya.

Sedangkan Urban Redevelopment Authority mengemukakan komponenkomponen guna mengatur ruang publik yang baik dapat diwujudkan dengan akronim PLACES yang terdiri dari: 1) People and Programming, 2) Lush Landscaping, 3) Accessibility, 4) Comfort, 5) Exellence in design; Eye for detail; Engaging, 6) Sense of delight and Sharing of spaces.

\section{METODE PENELITIAN}

\subsection{Ruang Lingkup}

Ruang lingkup wilayah dalam penelitian ini meliputi seluruh Kota Surakarta, yang 5 (lima) tahun terakhir ini sedang gencar menggalakkan program penyediaan ruang publik, serta ditetapkan menjadi salah satu kandidat dalam Indonesia Most Livable City Index. Sedangkan ruang lingkup substansi yang diteliti adalah ruang publik berupa taman, lapangan, dan alun-alun, dengan aspekaspek antara lain: ketersediaan, jangkauan, aksesibilitas, kenyamanan, fasilitas, serta kegiatan penunjang. Penelitian ini menggunakan data pada tahun terakhir, yaitu 2016.

\subsection{Metode Analisis}

Pendekatan penelitian dalam mengukur tingkat kesesuaian ruang publik di Kota Surakarta dengan konsep livable city ini menggunakan pendekatan deduktif. Dalam pendekatan deduktif, peneliti menggunakan teori di awal penelitian sebagai kerangka kerja untuk keseluruhan penelitian.

Jenis penelitian mengenai tingkat kesesuaian ruang publik di Kota Surakarta dengan konsep livable city ini merupakan jenis penelitian kuantitatif. Jenis penelitian kuantitatif adalah metode penelitian yang berlandaskan pada filsafat positivisme, digunakan untuk meneliti pada populasi atau sampel tertentu, pengumpulan data menggunakan instrumen penelitian, analisis data bersifat kuantitatif/statistik, dengan tujuan untuk menguji hipotesis yang telah ditetapkan (Sugiyono, 2011).

\subsection{Variabel Penelitian}

Variabel yang digunakan dalam penelitian ini dapat dilihat pada Tabel 1. berikut ini.

Tabel 1. Variabel Penelitian

\begin{tabular}{|l|l|}
\hline Variabel & Sub Variabel \\
\hline
\end{tabular}

\begin{tabular}{|c|c|}
\hline \multirow{2}{*}{$\begin{array}{l}\text { Ketersediaan } \\
\text { Ruang Publik }\end{array}$} & Jumlah Ruang Publik \\
\hline & Luas Ruang Publik \\
\hline $\begin{array}{l}\text { Jangkauan } \\
\text { Ruang Publik }\end{array}$ & - \\
\hline \multirow{2}{*}{$\begin{array}{l}\text { Aksesibilitas } \\
\text { Ruang Publik }\end{array}$} & Transportasi Umum \\
\hline & Jalur Pejalan Kaki \\
\hline \multirow{8}{*}{$\begin{array}{l}\text { Kenyamanan } \\
\text { Ruang Publik }\end{array}$} & Estetika \\
\hline & Keteduhan \\
\hline & Angin \\
\hline & Hujan \\
\hline & Kebisingan \\
\hline & Keamanan \\
\hline & Sosialisasi \\
\hline & Berbagi Ruang \\
\hline \multirow{2}{*}{$\begin{array}{l}\text { Fasilitas Ruang } \\
\text { Publik }\end{array}$} & Kualitas \\
\hline & Kecukupan \\
\hline $\begin{array}{l}\text { Kegiatan } \\
\text { Penunjang } \\
\text { Ruang Publik }\end{array}$ & - \\
\hline
\end{tabular}

Dalam melakukan pengumpulan data, dilakukan pendekatan terhadap dua jenis data dengan menggunakan pendekatan data primer dan data sekunder. Teknik pengumpulan data dengan menggunakan pendekatan data primer pada penelitian ini dilakukan dengan observasi lapangan, wawancara, dan kuesioner untuk data kondisi lingkungan, fasilitas, serta kegiatan penunjang ruang publik. Sedangkan teknik pengumpulan data dengan menggunakan pendekatan data sekunder pada penelitian ini dilakukan dengan teknik studi dokumen untuk data mengenai jumlah, luas, dan persebaran ruang publik, jumlah penduduk, rute transportasi umum, persebaran tempat transit, serta jalur pejalan kaki.

Populasi dalam penelitian ini adalah ruang publik di Kota Surakarta, yang berupa taman, lapangan, dan alun-alun. Oleh karena itu, populasi responden yang digunakan adalah masyarakat pengguna ruang publik berupa taman, lapangan, dan alun-alun di Kota Surakarta. Oleh karena jumlah populasi dalam penelitian ini tidak diketahui secara pasti, untuk menentukan jumlah sampel yang akan digunakan, dilakukan penghitungan dengan menggunakan rumus menurut Wibisono dalam Riduwan dan Akdon (2013) sebagai berikut.

$n=\left[\frac{Z_{\alpha / 2} \cdot \sigma}{e}\right]^{2}$

$n=\left[\frac{(1,96) \cdot(0,25)}{0,05}\right]^{2}$

$n=96,04$

Jumlah minimal sampel kuesioner dalam penelitian ini adalah 96,04 dan agar lebih mudah maka peneliti mengambil sampel 
sebanyak 100 responden. Distribusi sampel kuesioner dalam penelitian ini dapat dilihat pada Tabel 2. berikut ini.

Tabel 2. Distribusi Sampel

\begin{tabular}{|l|l|l|l|}
\hline \multirow{2}{*}{ Kecamatan } & \multicolumn{3}{|l|}{ Sampel Pengguna } \\
\cline { 2 - 4 } & Taman & Lapangan & $\begin{array}{l}\text { Alun- } \\
\text { Alun }\end{array}$ \\
\hline Laweyan & 5 & 15 & 0 \\
\hline Serengan & 3 & 7 & 0 \\
\hline $\begin{array}{l}\text { Pasar } \\
\text { Kliwon }\end{array}$ & 2 & 7 & 3 \\
\hline Jebres & 15 & 16 & 0 \\
\hline Banjarsari & 5 & 22 & 0 \\
\hline Total & $\mathbf{3 0}$ & $\mathbf{6 7}$ & $\mathbf{3}$ \\
\hline
\end{tabular}

\subsection{Teknik Analisis}

Teknik analisis yang digunakan dalam penelitian ini merupakan teknik analisis skoring. Teknik analisis skoring dilakukan dengan 2 (dua) tahapan, yaitu: analisis skoring tingkat kesesuaian ruang publik dengan konsep livable city tiap variabel dan skoring tingkat kesesuaian ruang publik dengan konsep livable city secara keseluruhan.Untuk menentukan skor tingkat kesesuaian, baik untuk masing-masing variabel maupun secara keseluruhan, digunakan langkah-langkah sebagai berikut:

1. Menentukan interval yang dilakukan dengan mengurangi nilai maksimal dengan nilai minimal.

2. Menentukan banyak kelas interval berdasarkan kategori tingkat kesesuaian, yaitu 3 kelas interval.

3. Menentukan panjang kelas interval dengan membagi interval dengan banyak kelas interval.

4. Menentukan kelas interval.

5. Menghitung tingkat kesesuaian dengan menyesuaikan kelas interval tiap kategori tingkat kesesuaian.

\section{HASIL PENELITIAN}

\subsection{Ketersediaan Ruang Publik}

Berdasarkan data yang diperoleh, dapat diketahui bahwa Kota Surakarta telah menyediakan ruang publik berupa taman, lapangan, dan alun-alun sesuai dengan jumlah taman, lapangan, dan alun-alun minimal. Dengan kata lain, Kota Surakarta telah memenuhi standar pemenuhan jumlah ruang publik berdasarkan jumlah penduduk sebanyak $100 \%$. Meskipun begitu, jumlah taman dan lapangan di setiap kecamatan tidaklah sama, sebab terdapat kelurahan yang memiliki ruang publik berupa taman dan lapangan lebih dari satu. Di sisi lain, terdapat kelurahan yang tidak memiliki taman dan lapangan di kawasannya. Badan Pemberdayaan Masyarakat Kota Surakarta telah menginisiasi program Taman Cerdas dan Taman Pintar yang seharusnya diterapkan di seluruh kelurahan di Kota Surakarta. Namun program ini belum berjalan optimal karena belum semua kelurahan menerapkan program penyediaan taman tersebut.

Sedangkan dalam pemenuhan luas ruang publik, diketahui bahwa Kota Surakarta telah memenuhi standar pemenuhan luas ruang publik sebanyak $40 \%$. Kota Surakarta telah menyediakan ruang publik berupa taman sesuai dengan luas taman minimal. Namun untuk ruang publik berupa lapangan dan alunalun belum sesuai dengan standar luas minimal, yakni lebih sedikit dibandingkan luas minimal yang telah ditetapkan.

Dari hasil analisis, ketersediaan ruang publik di Kota Surakarta tingkat kesesuaiannya dengan konsep livable city tinggi dan bernilai 3 (tiga).

\subsection{Jangkauan Ruang Publik}

Berdasarkan data yang diperoleh, diketahui bahwa ruang publik berupa taman belum dapat menjangkau seluruh kawasan, yakni sebesar $76,04 \%$ dari total luas wilayah. Hal ini dikarenakan persebaran taman di Kota Surakarta yang tidak merata, terutama di bagian utara, timur, dan barat. Jangkauan ruang publik berupa taman dapat dilihat pada Lampiran 1. Ruang publik berupa lapangan juga belum menjangkau seluruh kawasan, yakni sebesar $94,74 \%$ dari total luas wilayah, dengan adanya sebagian Kecamatan Banjarsari, Kecamatan Jebres, serta Kecamatan Pasar Kliwon yang belum terjangkau lapangan. Jangkauan ruang publik berupa lapangan dapat dilihat pada Lampiran 2. Sedangkan untuk ruang publik berupa alunalun sudah menjangkau seluruh Kota Surakarta, karena jangkauan pelayanan minimal alun-alun kota adalah seluruh kawasan kota. Berdasarkan hasil rata-rata jangkauan ketiga tipologi ruang publik tersebut, ruang publik di Kota Surakarta telah menjangkau 90,27\% dari luas wilayah.

Dari hasil analisis, jangkauan ruang publik di Kota Surakarta tingkat kesesuaiannya dengan konsep livable city tinggi dan bernilai 3 (tiga). 


\subsection{Aksesibilitas Ruang Publik}

Berdasarkan data yang diperoleh, sebagian besar ruang publik di Kota Surakarta sudah terjangkau oleh rute trayek transportasi umum, sebesar 90,12\% dari total luas wilayah. Ruang publik yang berada di kawasan pusat kota merupakan yang paling banyak dilewati oleh rute trayek angkutan umum. Sedangkan di bagian utara Kota Surakarta merupakan kawasan yang paling sedikit dilewati oleh rute trayek transportasi umum. Jangkauan rute trayek transportasi umum dapat dilihat pada Lampiran 3. Sedangkan tempat transit hanya menjangkau ruang publik di bagian pusat kota saja, atau sekitar $41,98 \%$ dari total luas wilayah. Persebaran tempat transit yang masih terpusat di jalan-jalan utama kawasan pusat Kota Surakarta ini mengakibatkan ruang publik yang berada di bagian utara Kota Surakarta, yakni Kecamatan Banjarsari dan Kecamatan Jebres bagian utara belum terjangkau oleh tempat transit. Kondisi serupa juga terjadi pada ruang publik di bagian timur Kecamatan Pasar Kliwon serta bagian utara dan selatan Kecamatan Laweyan. Jangkauan tempat transit dapat dilihat pada Lampiran 4.

Selain itu, ruang publik yang sudah menyediakan jalur pejalan kaki baru sebagian kecil, sebesar 19,75\% dari total jumlah ruang publik. Ruang publik yang berada di sekitar permukiman warga di tiap kelurahan jarang yang menyediakan jalur pejalan kaki, karena adanya anggapan bahwa pengguna ruang publik di tiap kelurahan yang ada hanya masyarakat yang bertempat tinggal di kelurahan tersebut saja. Namun sebenarnya, jika terdapat event-event menarik di ruang publik tersebut, mereka yang bertempat tinggal di luar wilayah akan mendatangi lokasi tersebut, sehingga jalur pejalan kaki perlu diperhatikan.

Dari hasil analisis, aksesibilitas ruang publik di Kota Surakarta tingkat kesesuaiannya dengan konsep livable city rendah dan bernilai 1 (satu).

\subsection{Kenyamanan Ruang Publik}

Berdasarkan data yang diperoleh, dapat diketahui total nilai dari penilaian responden terhadap kenyamanan lingkungan ruang publik adalah 1858. Nilai tersebut diperoleh dari penjumlahan nilai dari 8 (delapan) aspek, meliputi: estetika, keteduhan, angin, perlindungan dari hujan, kebisingan, keamanan, kegiatan sosialisasi, dan berbagi ruang. Aspek keamanan merupakan aspek yang mempunyai nilai tertinggi dalam penilaian kenyamanan ruang publik. Hal ini berarti keamanan di ruang publik Kota Surakarta sudah cukup baik, yang berdasarkan hasil analisis peneliti diwujudkan dengan jarang ditemukannya pengguna ruang publik yang mengalami tindakan kejahatan. Sedangkan aspek yang mendapatkan nilai terendah dalam penilaian kenyamanan ruang publik adalah aspek perlindungan dari hujan. Hal ini dikarenakan baru sebagian kecil ruang publik yang sudah menyediakan tempat untuk berlindung dari hujan, seperti: kanopi, gazebo, dan lain sebagainya. Oleh karena itu, pengguna ruang publik di Kota Surakarta merasa memerlukan lebih banyak penyediaan tempat-tempat untuk berlindung tersebut, sehingga bila cuaca berubah menjadi turun hujan para pengguna tetap dapat merasa nyaman.

Dari hasil analisis, kenyamanan ruang publik di Kota Surakarta tingkat kesesuaiannya dengan konsep livable city sedang dan bernilai 2 (dua).

\subsection{Fasilitas Ruang Publik}

Berdasarkan data yang diperoleh, diketahui total nilai penilaian pengguna terhadap ketersediaan fasilitas penunjang ruang publik adalah 1071. Nilai tersebut didapatkan dari hasil penjumlahan nilai dari 7 (tujuh) aspek, meliputi: kualitas dan kecukupan fasilitas olahraga, kualitas dan kecukupan fasilitas bermain, kualitas dan kecukupan tempat duduk dan penerangan, serta mewadahi kegiatan rekreasi/jalan-jalan. Ketujuh aspek tersebut dibagi ke dalam 3 (tiga) macam sesuai dengan tipologi ruang publik yang digunakan dalam penelitian ini. Aspek dalam ruang publik berupa taman yang mempunyai nilai tertinggi dibandingkan aspek lain adalah kecukupan tempat duduk dan penerangan. Hal ini berarti tempat duduk dan lampu yang tersedia di ruang publik sudah cukup sesuai dengan kebutuhan pengguna, yang didominasi oleh ibu rumah tangga yang mengantarkan anak-anaknya bermain di taman. Untuk ruang publik berupa lapangan, aspek kualitas dan kecukupan fasilitas olahraga di ruang publik berupa lapangan memiliki penilaian paling tinggi dibandingkan dengan aspek lain. Hal ini sejalan dengan tujuan utama para pengguna lapangan untuk 
menggunakan fasilitas olahraga yang terdapat di tempat tersebut. Sedangkan untuk ruang publik berupa alun-alun, dapat diketahui bahwa sebagian besar pengguna alun-alun merupakan keluarga yang mendatangi tempat tersebut untuk sekedar berekreasi. Oleh karena itu, kemampuan alun-alun untuk mewadahi kegiatan rekreasi/jalan-jalan pengguna mendapatkan penilaian paling tinggi.

Dari hasil analisis, fasilitas ruang publik di Kota Surakarta tingkat kesesuaiannya dengan konsep livable city sedang dan bernilai 2 (dua).

\subsection{Kegiatan Penunjang Ruang Publik}

Berdasarkan data yang diperoleh, dapat diketahui bahwa baru sebagian kecil ruang publik yang mengadakan kegiatan penunjang, yakni sebesar 20,99\% dari jumlah ruang publik secara keseluruhan. Berbagai macam kegiatan penunjang tersebut dapat dikelompokkan menjadi: 1) bazaar, 2) pameran, 3) pertunjukan, 4) arena hiburan, 5) turnamen, 6) perkumpulan klub, serta 7) acara pemilihan. Jangka waktu pelaksanaan tiap kegiatan penunjang berbeda-beda tiap jenisnya. Kegiatan penunjang berupa bazaar diadakan dengan jangka waktu setiap bulan. Kegiatan penunjang berjenis arena hiburan diadakan dengan jangka waktu setiap 6 (enam) bulan sekali. Ruang publik berupa lapangan paling banyak mengadakan kegiatan penunjang berupa turnamen, dengan jangka waktu setahun sekali. Untuk kegiatan penunjang berupa pameran, pertunjukan, serta pemilihan, jangka waktu pelaksanaan kesemua kegiatan penunjang tersebut setahun sekali. Sedangkan kegiatan penunjang berupa perkumpulan klub, diadakan setiap minggu sekali. Ruang publik berupa lapangan yang paling banyak mengadakan kegiatan penunjang secara rutin, dengan 3 (tiga) jenis kegiatan penunjang, yaitu: turnamen, bazaar, dan arena hiburan. Sedangkan ruang publik berupa taman, walaupun jumlahnya tidak sebanyak lapangan, namun jenisnya lebih banyak, antara lain: bazaar, perkumpulan klub, pameran, pertunjukan, serta acara pemilihan.

Dari hasil analisis, kegiatan penunjang ruang publik di Kota Surakarta tingkat kesesuaiannya dengan konsep livable city rendah dan bernilai 1 (satu).

\subsection{Analisis Skoring Tingkat Kesesuaian Ruang Publik di Kota Surakarta dengan Konsep Livable City}

Berdasarkan penghitungan, jumlah skor dari variabel-variabel dalam penelitian ini adalah 12 (dua belas), atau termasuk ke dalam kategori tingkat kesesuaian sedang. Meskipun demikian, masih terdapat beberapa aspek dalam ruang publik di Kota Surakarta kesesuaiannya masih rendah, yaitu dalam hal aksesibilitas serta fasilitas penunjang ruang publik.

\section{KESIMPULAN}

Dari hasil analisis, dapat disimpulkan bahwa tingkat kesesuaian ruang publik di Kota Surakarta dengan konsep livable city termasuk ke dalam kategori tingkat kesesuaian sedang. Variabel tingkat kesesuaian ruang publik dengan konsep livable city yang mendapatkan nilai paling tinggi adalah ketersediaan ruang publik serta jangkauan ruang publik. Variabel dengan nilai sedang, antara lain: kenyamanan ruang publik dan fasilitas penunjang ruang publik. Meskipun demikian, dalam hal aksesibilitas ruang publik serta kegiatan penunjang ruang publik, di Kota Surakarta tingkat kesesuaiannya masih rendah. Untuk itu, diperlukan kerjasama dari berbagai pihak dalam meningkatkan aspek yang tingkat kesesuaiannya masih rendah tersebut, untuk mewujudkan ruang publik di Kota Surakarta sesuai konsep livable city.

\section{REFERENSI}

AARP Public Policy Institute. 2015. "AARP Livability Index".

Carr, Stephen, Leaneg Rivlin, Stone Mark, and Adre M. 1992. Public Space. Australia: Press Syndicate of University of Cambridge.

Ching, Francis D.K. 1997. Arsitektur: Bentuk, Ruang dan Susunannya. Jakarta: Erlangga.

Evans, P, ed. 2002. "Livable Cities? Urban Struggles for Livelihood and Sustainability". USA: University of California Press Ltd.

Hahlweg, D dalam Lennard, S. H., S von Ungern-Sternberg, H. L. Lennard, eds. 1997. "Making Cities Livable". USA: Gondolier Press.

Hakim, Rustam. 1987. Unsur Perancangan dalam Arsitektur Lansekap. Jakarta: Bina Aksara. 
Ikatan Ahli Perencanaan Indonesia. 2009. "Indonesia Most Livable City Index 2009".

Prakoso, Sidik Taufik. 2013. "Ruang Terbuka Hijau Solo Baru 12\%". http://www.solopos.com/ (Diakses tanggal 17 Mei 2016).

Pratiwi, Gustyanita. 2012. "Tahun 2015 Solo Menjadi Kota dalam Kebun". http://www.SWA.co.id/ (Diakses tanggal 17 Mei 2016).

Salzano, E dalam Lennard, S. H., S von Ungern-Sternberg, H. L. Lennard, eds. 1997. "Making Cities Livable". USA: Gondolier Press.

Scurton, Roger. 1984. Public Space and The Classical Vernacular. Singapore: The Public Interest.
Sugiyono. 2011. Metode Penelitian Kuantitatif Kualitatif dan $R \& D$. Bandung: Penerbit Alfabeta.

Timmer, Vanessa, and Nola-Kate Seymoar. 2006. "The Livable City". Makalah disampaikan pada The World Urban Forum. Canada, 10-12 Maret 2006.

Urban Redevelopment Authority. 2014. "Master Plan Public Space".

Wibisono dalam Riduwan dan Akdon. 2013. Rumus dan Data dalam Analisis Statistika. Bandung: Penerbit Alfabeta.

Widodo, Joko. 2013. "RTH di Solo Baru Mencapai 12 Persen". http://www.antarajateng.com/ (Diakses tanggal 17 Mei 2016). 


\section{LAMPIRAN 1}

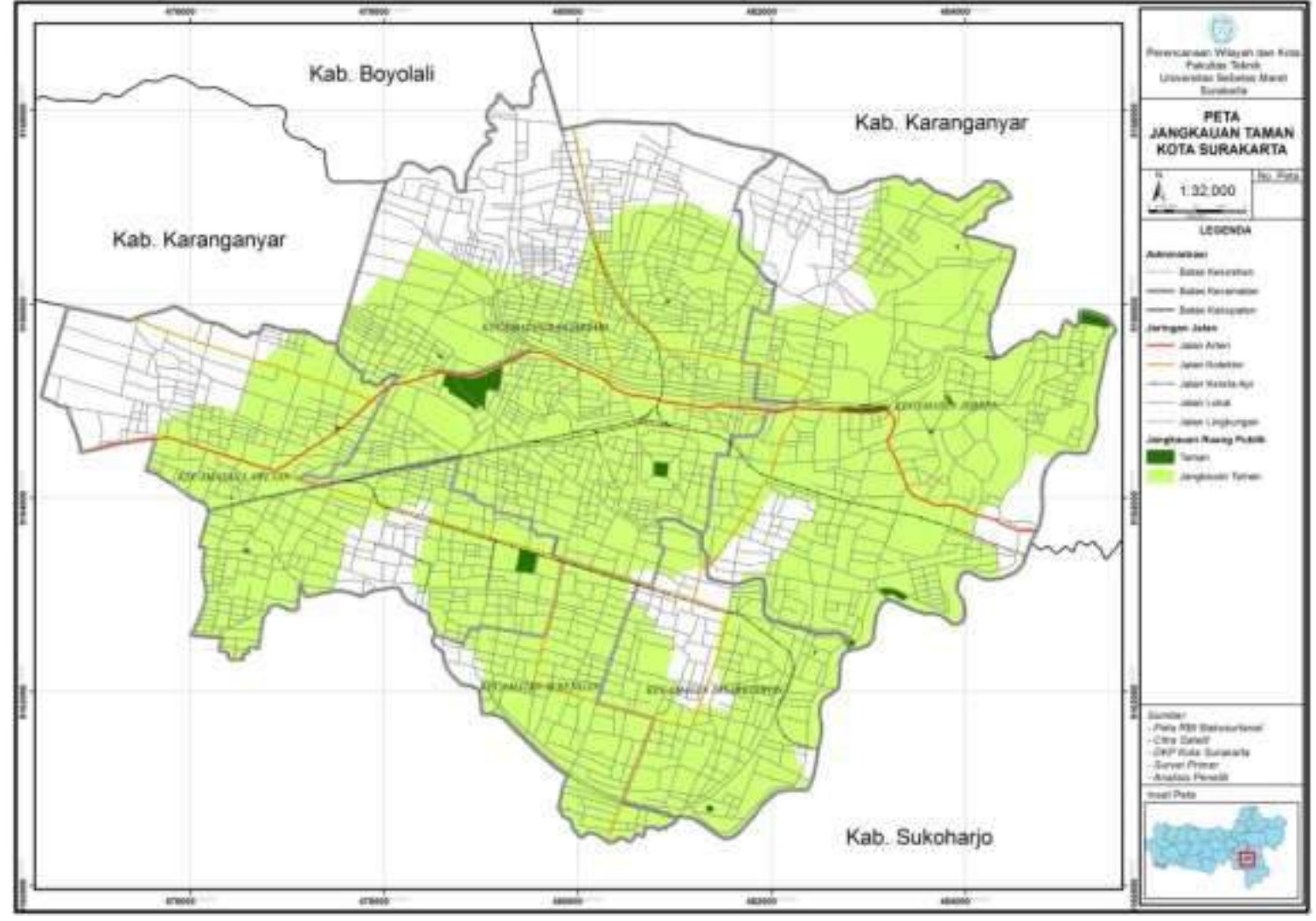

Gambar 1. Peta Jangkauan Taman Kota Surakarta

(Dinas Kebersihan dan Pertamanan Kota Surakarta dan Survei Primer, 2016)

\section{LAMPIRAN 2}

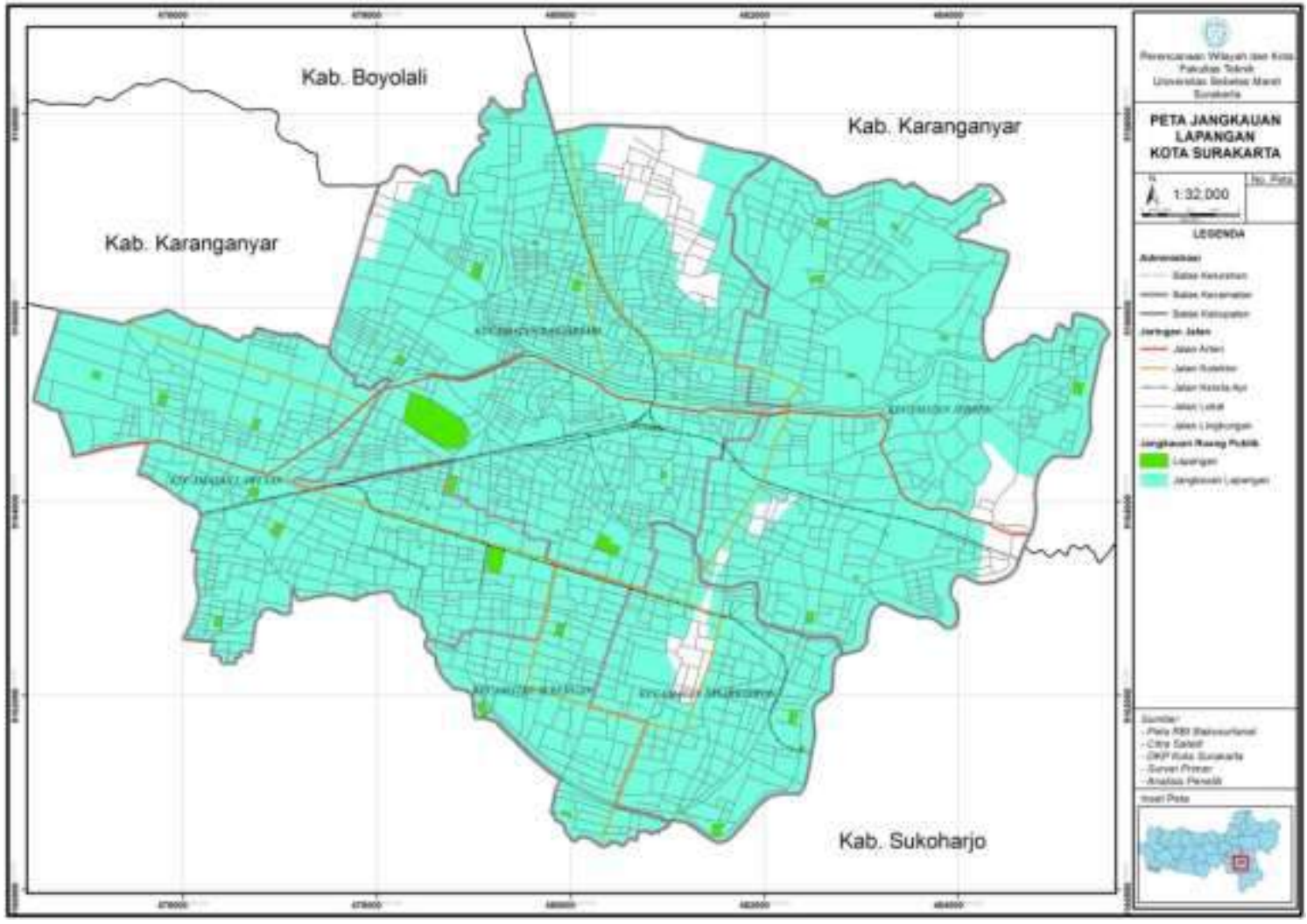

Gambar 2. Peta Jangkauan Lapangan Kota Surakarta

(Dinas Kebersihan dan Pertamanan Kota Surakarta dan Survei Primer, 2016) 


\section{LAMPIRAN 3}

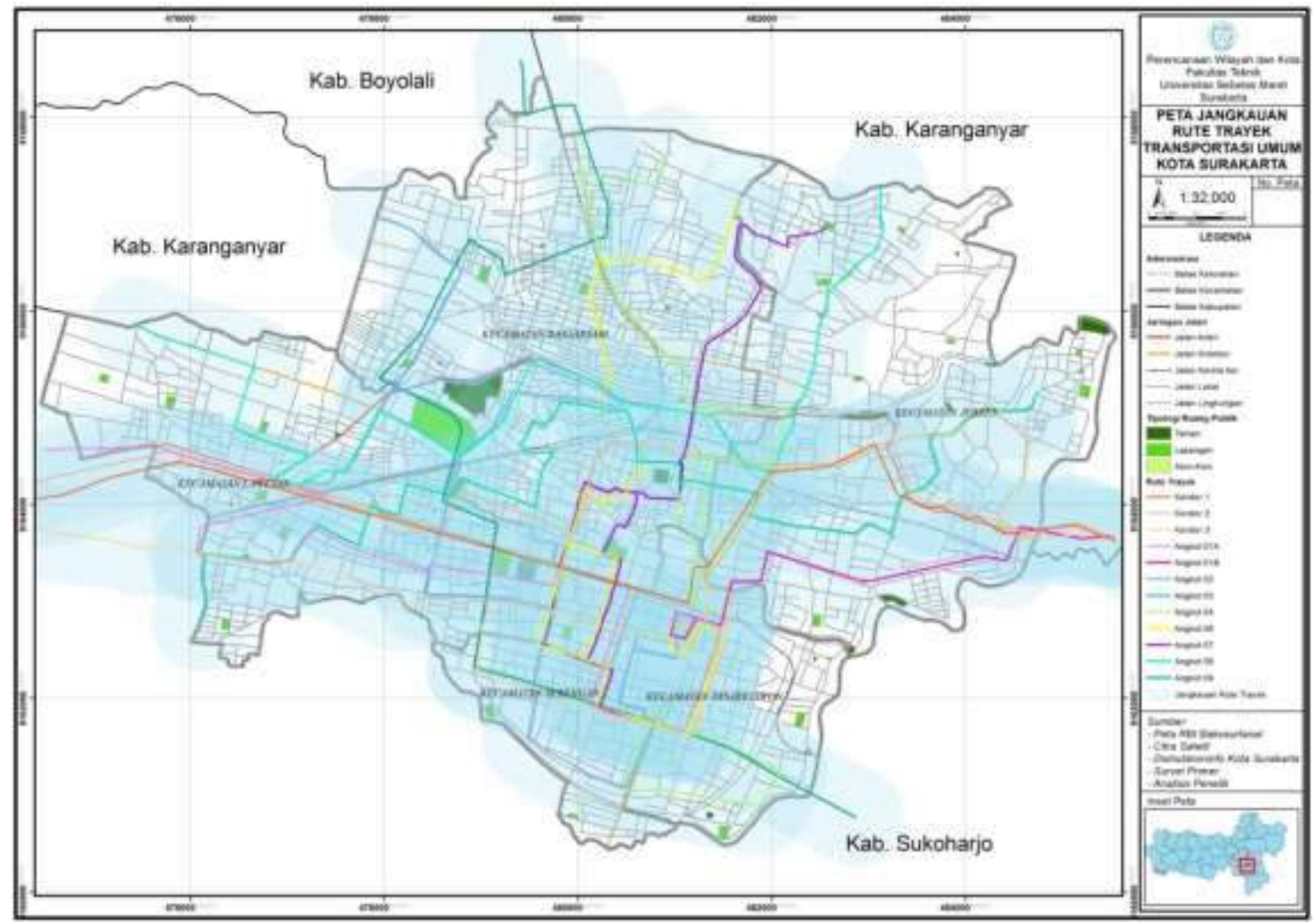

Gambar 3. Peta Jangkauan Rute Trayek Transportasi Umum Kota Surakarta

(Dinas Perhubungan, Komunikasi, dan Informatika Kota Surakarta dan Survei Primer, 2016)

\section{LAMPIRAN 4}

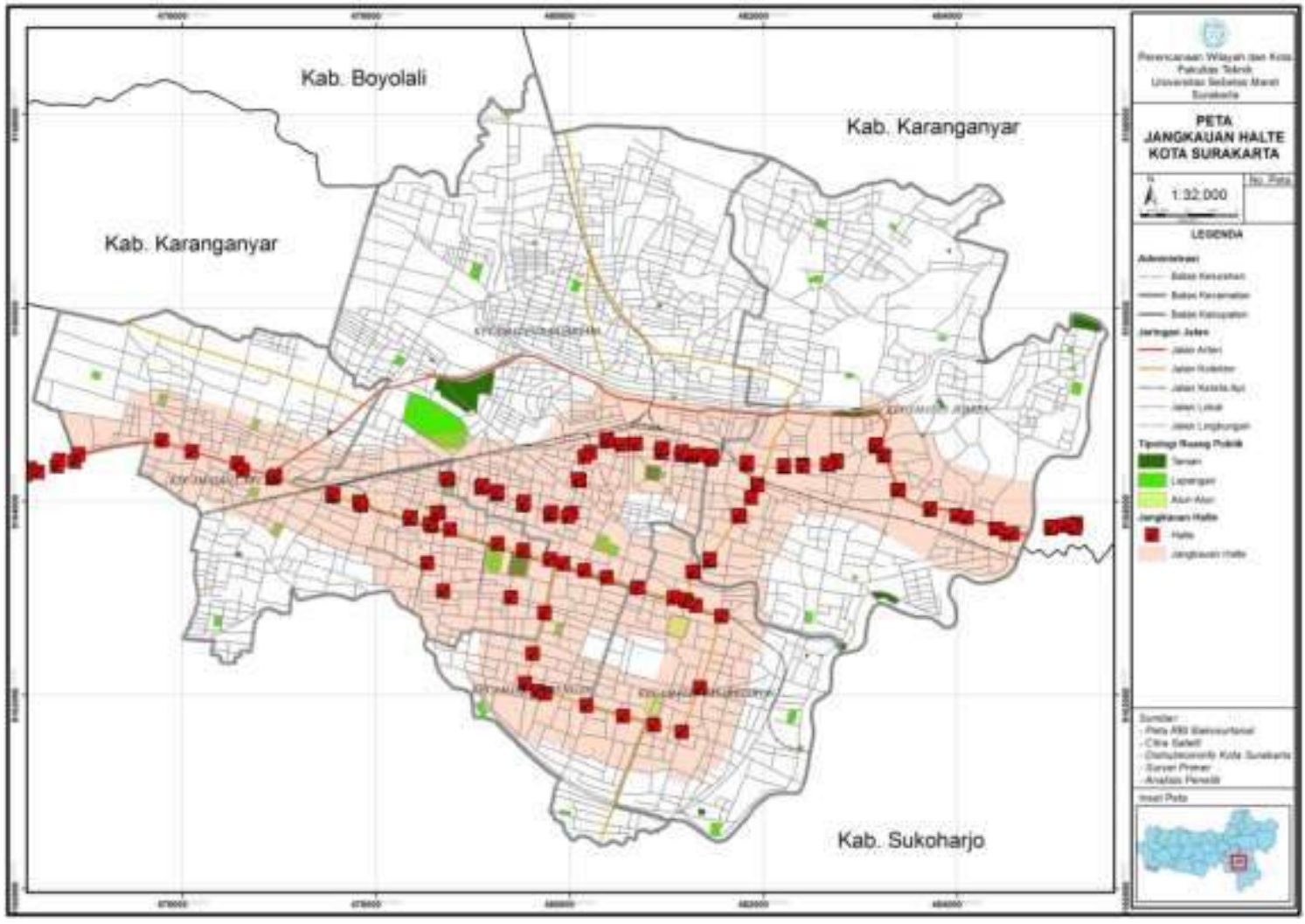

Gambar 4. Peta Jangkauan Tempat Transit Kota Surakarta

(Dinas Perhubungan, Komunikasi, dan Informatika Kota Surakarta dan Survei Primer, 2016) 